\title{
The Profile of In-service EFL Teachers' Professional and Pedagogical Competence Development
}

\author{
Esti Kurniasih \\ Universitas Negeri Surabaya \\ Surabaya, Indonesia \\ estikurniasih@unesa.ac.id
}

\author{
Ririn Pusparini \\ Universitas Negeri Surabaya \\ Surabaya, Indonesia \\ ririnpusparini@unesa.ac.id
}

\begin{abstract}
Being a teacher is a professional career. As a professional teacher, he/she should be able to understand his/her students, master the teaching materials, plan-conduct-andevaluate the learning process, and develop his/her professionalism and education. In other words, professional teachers should have professional and pedagogical competence. To get those two competences, teacher can improve his/her professional competence through academic education like universities or colleges; while pedagogical competence can be obtained from professional education like in-service education program (PPG). PPG is a program which aims at creating professional teachers who have competence in planning, conducting, and evaluating the learning process, supervising and training the learners, doing a research, and developing their professionalism continually. Further, this paper is going to elaborate in-service teachers' professional and pedagogical competence during in-service education program (PPG). To be specific, this paper is going to describe in-service teachers' English knowledge on understanding texts and how those texts work and their competence in designing lesson plan. The results show that the students of in-service education program (PPG) have to improve their both professional and pedagogical competence by doing a lot of exercises in understanding texts and how those texts work (concept and learning materials) as well as doing many practices in designing a good lesson plan.
\end{abstract}

Keywords-in-service education program (PPG), in-service teachers, professional competence, pedagogical competence

\section{INTRODUCTION}

Indonesia is a big country whose area is very large and the people are heterogeneous, not only geographically but also socioculturally. Because of that, there must be various problems happened, especially for remote area or area that is included to border of this country. The biggest problem is that the education matter is in imbalanced distribution. It is related to the distribution of teacher, competencies of a teacher, and learning sources. Another problem is the people awareness of how important education is still very low. To solve those problems, the fastest way is to develop a program that is Training Program for Professional Teachers in Remote Area (Program Pendidikan Profesi Guru Sarjana Mendidik di Daerah 3T/PPG SM3T).
According to UU No.20/2013, professional program is one year program for undergraduate students which aims to prepare them to have competencies as their need. The goal of this program as stated in Ministerial Decree No. 87/2013[1] is to produce prospective teachers who are competent in planning, conducting, and evaluating the learning process, as well as in analyzing the result of evaluation and conducting the research to support their competencies.

The learning outcomes of this program are described from four teacher's competences, those are: pedagogical competence that covers planning, conducting, and analyzing learning process; ethics competence that is related to good attitude for appropriate religion, norms, and culture; social competence that is related to the ability of communicating and interacting with others or good interpersonal; and professional competence that is related to the ability of mastering the relevant concepts and learning materials. Moreover, the structure of the curriculum of in-service education program (PPG) is as below:

TABLE I. THE STRUCTURE OF PPG CURRICULUM

\begin{tabular}{|c|l|c|}
\hline No. & \multicolumn{1}{|c|}{ Curriculum Content } & Proportion \\
\hline 1. & $\begin{array}{l}\text { Workshop of designing the teaching set of } \\
\text { subject-specific pedagogy }\end{array}$ & $60 \%$ \\
\hline 2. & Teaching Practice & $40 \%$ \\
\hline
\end{tabular}

As stated previously, being a professional teacher, he/she should be able to understand his/her students, master the teaching materials, plan-conduct-and evaluate the learning process, and develop his/her professionalism and education. In other words, professional teachers should have professional and pedagogical competence [2]. Regarding professional and pedagogical competence, teachers should have knowledge on texts and how those texts work (concept and learning materials) and also on syllabus, lesson plan, and how they design or plan a lesson plan. Related to texts, there are 2 kinds of texts: dialogues (transactional and interpersonal dialogues) and monologues (short functional texts and longer texts/genres/text types).

Texts are pieces of written or spoken language created for a particular purpose. When we speak or write, we create texts. 
When we listen, read or view texts, we interpret them for meaning. A good piece of text requires the creator/author to make the right choices from the language system; choices about words, sentences, processes and features. These choices will reflect his/her purpose and context [3].

McCarty [4] asserts that language serves interactional and transactional functions. This classification is much similar to that of Brown and Yule [5] that is in interactional talks, people use language for establishing social relations and expressing personal attitude, while in transactional ones they use language to achieve optimal and efficient transference of information. As transactional talks are message oriented, cohesive and accurate communication is highly required [6]. Some of the speech acts which serve transactional function included in the 2013 Curriculum are ordering/commanding, requesting, promising, warning, threatening, refusing, blaming, complaining, etc.

Another language expert, Halliday [7] asserts that language as a social phenomenon has different functions such as textual, ideational, and interpersonal. The interpersonal function of language involves communication strategies by which people maintain and/or establish social relationships, or people use language to help them establish social order and maintain good relations with other people [8]. Since interpersonal exchange is primarily conducted to maintain good social relationship, it commonly involves politeness and range of formality determined by the relative power and social distance between the speaker and hearer. The more distance between the speaker and hearer, the more formal and polite the expression will be. There are some examples of interpersonal functions of English language, such as introducing, apologizing, thanking, complimenting, congratulating, wishing good luck, showing sympathy, care/concern, condolence, anger, annoyance, happiness, disappointment, boredom, etc.

Short functional text is a short text that has particular meaning and purpose, and can be used in our daily life. It may be in the form of announcements, invitation, greeting cards, short message, shopping list, notice, announcement, etc. Like short functional texts, longer texts/genres/text types are also created for certain purposes, such as for persuading, informing, explaining, describing, instructing, retelling, and entertaining the readers or listeners. There are various kinds of text types, they are: narration, recount, description, report, procedure, explanation, discussing, exposition, reviews, news items, etc.

In addition to professional competence, pedagogical competence is another competence that professional teachers should possess. Here, they have to know and understand about syllabus, lesson plan, and how they should design a good lesson plan. Lesson plan is very crucial thing in teachinglearning process since the success or failure of teachinglearning activities is influenced by teacher's lesson plan. Lesson plan or course design is an instructional plan describing learning objectives, teaching-learning materials, teaching-learning methods and techniques, teaching-leaning media, learning sources, and some means of assessments. Brown [9] proposes the essential elements of a lesson plan such as goals, objectives, materials and equipment, procedures, evaluation, and extra-class work. Goal is an overall purpose to be accomplished by the end of the class period. Objective is the explicit statement of what the learners can gain from the lesson. While based on Ministerial Decree (Permendikbud) No. 22 tahun 2016 [10], components of a lesson plan are school identity, subject/course identity, grade/semester, theme/sub theme, time allocation, learning objectives, Basic Competences (KD) and indicators, learning materials, learning methods/techniques, learning media, learning sources, learning activities, and assessment. Obviously, to be able to design an English lesson plan well, English teachers are required to study and understand thoroughly core competence and basic competence, formulate the indicators that must be fulfilled by the learners, formulate learning objectives, select and grade good teaching-learning materials, determine teaching-learning methods, choose appropriate teaching technique and media, conduct test and evaluation, determine time allocation, and inform the learning sources to the learners. Finally, seeing the importance of these two competences for becoming a professional teacher, therefore, this paper is further going to elaborate in-service teachers' professional and pedagogical competence during inservice education program (PPG).

\section{METHOD}

This paper is a descriptive research-based paper that describes the profile of In-service EFL teachers' professional and pedagogical competence. According to Wiersma [11], descriptive research is a research that describes condition of a phenomenon in a particular time. Besides, this research searches some variables naturally in a particular time. The objects of the study are the students of in-service education program (PPG)'s test result and lesson plans. The data of the study are the results of Formative Test 1 and also the results of the students' lesson plan. The instruments used in this research are the observation sheets (check lists) that are used to observe and analyze the results of Formative Test 1 and the lesson plans of the students of in-service education program (PPG) of 2017.

To collect the data, the researchers conducted some procedures, those are: (1) the researchers came to the class of in-service education program (PPG) to see the lecturer who taught that class; (2) the researchers asked for a permission to conduct a research in that class; and (3) after getting a permission, the researchers started to collect the data, that is the results of Formative Test 1 and also the results of the students' lesson plan. After the data were collected, the researchers then conducted the next step, that is analyzing and describing the data by conducting the steps as follows: (1) the researchers read the results of Formative Test 1 and also the results of the students' lesson plan; (2) the researchers analyzed those data by using the provided instruments; (3) the researchers discussed together the results of analyzing the data; (4) the researchers drew a conclusion; and (5) the researchers started to present the result. 


\section{DISCUSSION}

\section{a. The Description of In-service Teachers' Professional Competence}

There are two kinds of tests that students have to take to pass this in-service education program (PPG), those are local examination and national examination. For the local examination, it is done offline and it contains pedagogy materials. However, the national examination is done online and it contains professional materials or English. This professional examination is like a burden for students to pass this program. Almost all students from all universities which conduct this program admit that to pass this exam or to achieve the target score is very difficult. Moreover, there is a different target score for this year that is 70 instead of 50. It is obvious that it will make students get more difficulties to reach the target score. To improve students' professional competence, the students are given professional test in every semester, namely Formative Test. It is also done to know their preparation before the national examination. And below is the result of the analysis of the students first Formative Test.

There are 55 items in this test that consist of the abilities in getting the specific information implicitly and explicitly, getting the main idea, getting the conclusion of the text, getting the general information, identifying the meaning of a word from the text, completing the paragraph with appropriate word, and arranging the sentences into good paragraph.

There are 22 students, and only one student is able to reach the target score. The items that seem very difficult for them are the test items number $1,2,7,9,18,25,28,34,44,52$, and 55. Not more than 10 students are able to choose the correct answer for those test items. Those items are related to the competence of getting the implicit information, getting the main idea, completing the paragraph with correct word, getting the main idea, getting the explicit information, and identifying the meaning of a word from the text. Obviously, the students' ability in doing the Formative Test is shown by the table below:

TABle 2: The RESUlt OF Formative TEST

\begin{tabular}{|c|l|c|c|c|}
\hline No. & $\begin{array}{c}\text { Indicators of the Test } \\
\text { Items }\end{array}$ & $\begin{array}{c}\text { The Number } \\
\text { of Test Items }\end{array}$ & $\begin{array}{c}\text { The Number } \\
\text { of Items that } \\
\text { can be } \\
\text { Answered }\end{array}$ & $\%$ \\
\hline 1 & $\begin{array}{l}\text { Getting the specific } \\
\text { information implicitly }\end{array}$ & 18 & 7 & 39 \\
\hline 2 & $\begin{array}{l}\text { Getting the specific } \\
\text { information explicitly }\end{array}$ & 12 & 11 & 92 \\
\hline 3 & Getting the main idea & 3 & 1 & 33 \\
\hline 4 & $\begin{array}{l}\text { Getting the conclusion } \\
\text { of the text }\end{array}$ & 2 & 1 & 50 \\
\hline 5 & $\begin{array}{l}\text { Getting the general } \\
\text { information }\end{array}$ & 6 & 3 & 50 \\
\hline 6 & $\begin{array}{l}\text { Identifying the meaning } \\
\text { of a word from the text }\end{array}$ & 4 & 3 & 75 \\
\hline 7 & $\begin{array}{l}\text { Completing the } \\
\text { paragraph with } \\
\text { appropriate word }\end{array}$ & 7 & 2 & 28 \\
\hline 8 & $\begin{array}{l}\text { Arranging the sentences } \\
\text { into a good paragraph }\end{array}$ & 3 & 0 & 0 \\
\hline
\end{tabular}

From the table above, it is crystal clear that students need to improve their competence in almost all indicators, especially for "arranging the sentences into a good paragraph", because all students are not able to answer that kind of test item. Moreover, students need to practice a lot by doing a lot of exercises in hope that they can reach the target score.

\section{b. The Description of In-service Teacher's Pedagogical Competence}

In line with the number of the students in this in-service education program (PPG), there are 22 lesson plans that were analyzed in this paper. Using the checklist provided by Pusat Kurikulum (2016), there are 8 components that are analyzed in those lesson plans, they are: (1) subject/course identity; (2) indicators; (3) learning objectives; (4) learning materials; (5) learning sources; (6) learning media; (7) learning activities; and (8) learning assessment. To be detail, the following is the explanation of the indicators of those components.

Subject/course identity is the first component in lesson plan analysis check list. The indicators of a good subject/course identity are writing in the lesson plans the unit of education level (junior or senior high school), grade/semester, the subject/course and its theme/sub theme, and the number of meetings as well as the time allocation. The second component in lesson plan analysis check list, i.e. indicators, comprises formulating indicators which are in line with basic competence, using action/operational words in formulating the indicators, and formulating indicators which include the domains of attitude, knowledge, and skill. For the third component, good learning objectives should be in line with the indicators, cover audience, behaviour, condition, and degree, be formulated based on time allocation and basic competence, and also consist of the domains of attitude, knowledge, and skill. Meanwhile, learning materials are considered as appropriate materials if they are selected based on the basic competence that is going to be developed, in line with the learning objectives, and based on the students' level and time allocation. Those learning materials can be delivered by making use of any other learning sources, such as natural or social resources, using textbook provided by the government, and/or using supplement learning materials downloaded from the internet. In addition to learning sources, those learning materials can be interesting if they are delivered using attractive learning media. Media themselves are considered as appropriate and interesting learning media if they are varied, developed based on the learning objectives, students' characteristics, and school condition, and involving students optimally. Learning activities are the next component that should be analysed in lesson plan analysis check list. The indicators of learning activities are developing learning activities that consist of pre, whilst, and post activities; cover the stages of scientific approach (i.e. observing, questioning, experimenting, associating, and communicating), include such domains as attitude, knowledge, and skill, and are developed based on the students' characteristics, time allocation, and learning media used. Finally, learning assessment is the last component in lesson plan analysis check list which should consists of the technique, the form, and the example of the test items in each domain (i.e. attitude, knowledge, and skill). 
Besides, learning assessment should also be developed based on the indicators formulated before and there should be rubric for the assessment (Pusat Kurikulum, 2016).

Derived from the above explanation, the lesson plans of the students of in-service education program (PPG) were finally analyzed based on the completeness of lesson plan components and the development of lesson plan. In terms of the completeness of lesson plan components, all the students' lesson plans have already stated all components of lesson plan, they are subject/course identity, indicators, learning objectives, learning materials, learning sources, learning media, learning activities, and learning assessment. However, in terms of the development of lesson plan, the result of the analysis showed that those students' lesson plans were developed differently. A few of them have developed and stated explicitly all the indicators of each component in lesson plan analysis checklist as stated above. While for the remaining lesson plans, many of the students did not mention and state all the indicators of each component explicitly in their lesson plan. The followings are the examples of the development of the students' lesson plans.

\section{Lesson Plan 1\#}

Lesson Plan 1\# has stated all components of lesson plan, they are subject/course identity, indicators, learning objectives, learning materials, learning sources, learning media, learning activities, and learning assessment. However, in terms of the development of lesson plan, there are some indicators which are missing or not stated explicitly in those lesson plan components. For example, in the indicator component, there are 2 indicators which are not in line with the basic competence (KD 4.1.8).

\section{KD 4.1.8:}

Menangkap makna teks naratif lisan dan tulis, berbentuk fabel pendek dan sederhana.

Indicators:

4.1.8.1 Menyusun gambar dan teks acak dengan urutan yang benar.

4.1.8.2 Mempresentasikan hasil teks acak yang telah disusun.

In the next component, i.e. learning objectives, there are 3 learning objectives which are not formulated based on the indicator, they are: $3.14 .1 .5 ; 3.14 .1 .6$; and 4.18.1.1.

Indicators:

3.14.1 Mengenal teks narrative berupa fable

3.14.2 Mengidentifikasi fungsi sosial dari teks fable

3.14.3 Mengidentifikasi struktur bahasa dari teks fable

3.14.4 Mengidentifikasi unsur kebahasaan dari teks

Learning objectives:

3.14.1.1 Diberikan beberapa teks narrative, siswa dapat mengenal teks narrative berupa fabel dengan benar.

3.14.1.2 Diberikan sebuah teks fabel, siswa dapat mengidentifikasi fungsi sosial pada teks fabel.
3.14.1.3 Diberikan sebuah teks fabel, siswa dapat mengidentifikasi struktur teks pada teks fabel.

3.14.1.4 Diberikan sebuah teks fabel, siswa dapat mengidentifikasi unsur kenahasaan pada teks fabel.

3.14.1.5 Diberikan 5 soal, siswa dapat merubah verb 1 menjadi verb 2, 4 diantaranya benar.

3.14.1.6 Diberikan teks fabel, siswa dapat merumuskan nilai moral pada teks.

KD 4.1.8:

Menangkap makna teks naratif lisan dan tulis, berbentuk fabel pendek dan sederhana.

Indicators:

4.1.8.1 Menyusun gambar dan teks acak dengan urutan yang benar.

4.1.8.2 Mempresentasikan hasil teks acak yang telah disusun.

Learning Objectives:

4.18.1.1 Diberikan beberapa gambar dengan teks yang acak, siswa mampu mengatur gambar dan teks acak dengan benar dan mempresentasikannya.

In another component, i.e. learning media are considered as appropriate and interesting learning media if they are varied, developed based on the learning objectives, students' characteristics, and school condition, and involving students optimally. However, in Lesson plan 1\#, the learning media used here is only pictures about animals. Thus, there is no variety on learning media used.

\section{Lesson Plan 2\#}

Lesson Plan 2\# has stated all components of lesson plan, they are subject/course identity, indicators, learning objectives, learning materials, learning sources, learning media, learning activities, and learning assessment. However, in terms of the development of lesson plan, there are some indicators which are missing or not stated explicitly in those lesson plan components. For example, in the learning objectives component, there are some learning objectives which do not cover degree. For example,

Learning Objectives:

a. Diberi learning log, peserta didik dapat untuk mengungkapkan rasa syukur atas kesempatan dapat belajar bahasa Inggris dan manfaatnya. (There is no degree)

b. Peserta didik dapat bertanggung jawab dan peduli untuk menjaga kebersihan lingkungan kelasnya. (There is no degree)

c. Peserta didik dapat menggunakan bahasa yang sopan untuk berkomunikasi dengan temannya baik di dalam maupun diluar kelas. (There is no degree)

d. Diberi gambar-gambar benda, siswa dapat mengenal kata benda yang ada di dalam kelas. (There is no degree) 
e. Diberi gambar-gambar benda, siswa dapat melafalkan kata benda yang ada di dalam kelas dengan intonasi dan pengucapan yang benar.

f. Diberi gambar ruangan kelas, siswa dapat mengidentifikasi struktur teks dan unsur kebahasaaan dari teks khusus berbentuk label nama. (There is no degree)

g. Diberi gambar ruangan kelas, siswa dapat memberi label secara berpasangan pada gambar tersebut sesuai dengan kata-kata yang sudah disediakan dengan benar.

h. Diberi latihan 10 soal, siswa dapat mengisi titik-titik dengan penggunaan "a/an, there is/there are", 8 di antaranya benar.

i. Diberi gambar ruang keluarga, siswa dapat memberi label secara individu. (There is no degree)

j. Diberi kalimat acak (jumble sentence) berdasarkan gambar, siswa dapat menyusun kata tersebut menjadi susunan kalimat yang benar.

Besides, among those 10 learning objectives above, there are 2 learning objectives which are not in line with the theme of the subject/course (Things in the classroom), they are learning objectives " $i$ " and " $j$ ". As we can see in the learning objectives above, learning objectives " $i$ " and " $j$ " deal with things in the living room. In line with the learning objectives, there are 2 learning materials that are not suitable with the theme of the subject/course, they are Task 3 and Task 4.

Task 3: Give the label for each object which you can find in the picture below! (The picture is about Things in the Living room)

Task 4: Arrange the jumble words below with the correct arrangement! (The words are about Things in the Living room).

\section{Lesson Plan 8\#}

Like the previous lesson plans, Lesson Plan 8\# also has stated all components of lesson plan, they are subject/course identity, indicators, learning objectives, learning materials, learning sources, learning media, learning activities, and learning assessment. However, in terms of the development of lesson plan, there are some indicators which are missing or not stated explicitly in those lesson plan components. For example, in the learning objectives component, there are some learning objectives which do not cover condition and degree. For example,

Learning Objectives:

Setelah melaksanakan serangkaian kegiatan pembelajaran, peserta didik dapat:

\section{1. bersemangat saat mendapat kesempatam belajar bahasa inggris.}

2.1.1 mengerjakan tugas individu tanpa mecontek milik teman.

2.1.2 masuk ke dalam kelas tepat waktu.

2.1.3 mengerjakan tugas individu maupun kelompok yang di berikan oleh guru dengan baik.
Besides, the learning media stated in this lesson plan is only pictures, thus, there is no variety on learning media used. Lesson Plan 3\# does not mention and state explicitly either the rubric of learning assessment in the domain of skill.

\section{Lesson Plan 18\#}

As the same as the other lesson plans, Lesson Plan 18\# also has stated all components of lesson plan, they are subject/course identity, indicators, learning objectives, learning materials, learning sources, learning media, learning activities, and learning assessment. However, in terms of the development of lesson plan, there are some indicators which are missing or not stated explicitly in those lesson plan components. For example, in the learning sources component, there is no textbook used here. Instead, the learning materials are downloaded from the internet. Besides, there is no variety on learning media used in this lesson plan, since there is only one media used here, that is picture about advertisement on event. For the learning assessment, the result of the analysis showed that the rubrics for assessing the students' knowledge and skill are combined into one.

\section{Lesson Plan 21\#}

Like the other lesson plans, Lesson Plan 21\# also has stated all components of lesson plan, they are subject/course identity, indicators, learning objectives, learning materials, learning sources, learning media, learning activities, and learning assessment. However, in terms of the development of lesson plan, there are some indicators which are missing or not stated explicitly in those lesson plan components. For example, in the indicators component, there are only indicators for Basic Competence (KD) 3 and 4. In line with the indicators, the student only formulated the learning objectives for KD 3 and 4 in her lesson plan. For the learning sources component, there is no textbook used here. Instead, the learning materials are downloaded from the internet. Besides, there is no variety on learning media used in this lesson plan, since there is only one media used here, that is a text about giving and doing commands/instructions.

\section{CONCLUSION}

Based on the result of the analysis of the students' Formative Test 1 score and the students' lesson plans above, it can be concluded that the students of in-service education program (PPG) have to improve their both professional and pedagogical competence by doing a lot of exercises in understanding texts and how those texts work (concept and learning materials) as well as doing many practices in designing a good lesson plan. Seeing the fact above, therefore, it is suggested that universities which conduct in-service education program (PPG) have to be strict in accepting the new students by revising the test items of entrance examination and assessing the students' prior knowledge on understanding texts, curriculum, syllabus, and lesson plan, so that the input will be better. 


\section{REFERENCES}

[1] Ministerial Decree No. 87/2013. The Goal of PPG Program. Jakarta.

[2] PPG Book, Panduan PPG. Pendidikan Profesi Guru 2017. Direktorat Pembelajaran. Jakarta: Direktorat Jenderal Pembelajaran dan Kemahasiswaan Kementerian Riset, Teknologi, dan Pendidikan Tinggi, 2017.

[3] PLPG Modul, Sertifikasi Guru dalam Jabatan 2014. Buku 4. Ramburambu Pelaksanaan Pendidikan dan Latihan Profesi Guru (PLPG). Jakarta: Kementerian Pendidikan dan Kebudayaan. Badan Pengembangan Sumber Daya Manusia Pendidikan dan Kebudayaan dan Penjaminan Mutu Pendidikan. Panduan PLPG 2013, 2014.

[4] M. McCarty, Discourse Analysis for Language Teachers. Cambridge: Cambridge University Press, 1991.

[5] G. Brown and G. Yule, Discourse Analysis. Cambridge: Cambridge University Press, 1983.

[6] J.C. Richards, The Language Teaching Matrix. Cambridge: Cambridge University Press, 1990.

[7] M.A.K. Halliday, An Introduction to Functional Grammar. Oxford: Oxford University Press, 1985.

[8] M. Finocchiario, Teaching English as a Second Language: From Theory to Practice. New York: Regents Publishing Company, 1974.

[9] H. D. Brown, Principles of Language Learning and Teaching. $3^{\text {rd }}$ Edition. Englewood Cliffs, NJ: Prentice Hall Regents, 1994.

[10] Ministerial Decree (Permendikbud) No. 22/2016. Components of a Lesson Plan. Jakarta.

[11] W. Wiersma, Research Methods in Education: An Introduction. New York: Pearson/Allyn and Bacon, Ltd, 2000. 